\title{
TOURISM AND RECREATION AS A DRIVING FORCE FOR FORECASTING BIODIVERSITY CHANGES: LAKE ENGURE WATERSHED AREA AS AN EXAMPLE
}

\author{
Maija Rozite and Daina Vinklere \\ Faculty of Geographical and Earth Sciences, University of Latvia, Alberta iela 10, Rīga, LV-1010, LATVIA \\ School of Business Administration Turiba, Graudu iela 68, Rīga, LV-1058, LATVIA \\ E-mail: maija.rozite@ turiba.Iv; daina.vinklere@ turiba.Iv
}

Communicated by Māris Kḷaviṇš

\begin{abstract}
The aim of the research was to evaluate tourism as a driving force and its pressures in the Lake Engure drainage basin area to forecast the possible long-term changes in biodiversity, in accordance with the DPSIR (Driving forces, Pressures, States, Impacts and Responses) framework, used by European Environment Agency (EEA). A map of the territory, divided into three tourism zones, was charted using secondary data sources, field research data and surveys of holidaymakers. Tourism enterprises and service providers as driving forces and the pressures created were evaluated, and statistical data on capacity of tourist accommodation, a number of people employed in the tourism industry and a number of tourists in the territory were summarised. Owners of summer houses and recreationists were surveyed in regard of their behaviour, the local services offered, the involvement of local municipality in the process and their future plans, and these factors were studied to evaluate the possible impact of second house tourism. The results indicate that tourism and recreation as a driving force is most active in the coastal zone, however, there is not a big tourist flow. In the future the territory will be mainly used for transit tourism, second-home tourism and recreation.
\end{abstract}

Key words: tourism, recreation, second homes, driving forces, impact.

\section{INTRODUCTION}

Nowadays the DPSIR (Driving forces, Pressure, State, Impact, Response) framework developed by the European Environment Agency (EEA) as a tool for structuring and analysing environment indicators, inter-connections between environment and social systems, is used for forecasting territory development and biodiversity changes in territories of different scales (Anonymous, 1999). It is possible to evaluate the pressures, determine the current situation and the impact created and forecast the possible changes by defining and analysing driving forces (Anonymous, 2005, 2007, 2010b).

Tourism nowadays is a significant economic industry with considerable force, the rapid expansion of which is raising some increasingly serious problems (Cohen, 2008). Tourism is also acknowledged in European Union documents (Anonymous, 2010b, p. 17) as a "significant and growing industry in the pan-European region, particularly impacting biodiversity in coastal, freshwater and forest ecosystems", and its impact on biodiversity in these ecosystems, similar to city development, should also be taken into consideration (Anonymous, 2010a). The volume of international tourism in Latvia has increased over the past decade (border crossings have increased 2.6 times in 2010 in comparison to 2000 , overnight travellers by 2.7). Latvian inhabitants made 1.4 million same day visits and 1 million overnight visits in Latvia in 2010. The capacity of tourist accommodation and services provided by tourism enterprises is increasing year by year (Anonymous, 2011). Therefore, analysis of the driving forces of the tourism industry, along with those of agriculture, transport and energy industries, should be considered as significant contributors to changes in the environment and its biodiversity (Anonymous, 2007).

Tourism can cause negative changes in biodiversity, such as disruption of breeding/feeding patterns, killing of animals as leisure (hunting), loss of habitats and change in species composition, and destruction of vegetation (Williams, 2009, p. 115). As a result of globalisation and international trade, tourists can bring in invasive alien species and change landscapes (Anonymous, 2005).

Taking into consideration social processes and their dynamics, demographic changes and increasingly affluent lifestyle can also be classified as change factors. With the increase in the proportion of the aged population and their affluence, 
the demand for tourism services and second homes is also increasing (Anonymous, 2005). This phenomenon is described in scientific literature as second-home tourism and amenity migration (Müller, 1999; Hall and Müller, 2004; Flogenfeldt, 2006). Therefore, apart from tourist accommodation, second-home tourism and their inhabitants' (holidaymakers') behaviour should also be studied in areas where there are second homes and summerhouses. As both territory guests as well as inhabitants use one and the same resources for recreation, it is not possible to ignore the pressure and impact created by recreation while analysing tourism pressure (Hall and Page, 2006).

Tourism as a driving force, its pressures and impact are characterised by the concept, ,tourism impact" in tourism literature, which is defined as ,the change in state of something related to tourism over time" (Hall and Lew, 2009, p. 41). Usually it is divided into three main impact dimensions - Environmental and Natural Resource dimension; Socio-Cultural dimension and Economic dimension. Mason emphasised the need for integrated research and considered that tourism impact is expressed through the interaction of these spheres and that impacts can be additionally divided into Environmental Economic impacts; Socio-Environmental impacts and Socio-Economic impacts. The tourism impact depends on the territory where the activity is being carried out, the scale of tourism (number of tourists involved), types of tourism, tourism activities, tourism infrastructure, life cycle stage of the destination, and tourism season (Mason, 2003, p. 30). Tourism impact is both positive as well as negative and can have simultaneously different impact on its stakeholders (Hall and Lew, 2009, p. 230).

The indicators necessary for the application of the DPSIR model are characterised in tourism literature as sustainable development indicators, the most significant of which are: the number of beds in tourist accommodations, transport used by tourists, the number of people employed in tourism, overnight stays, the proportion of tourism industry in economy, water and energy resources consumed by tourists, waste created by tourists, territory that is used for tourism and recreation activities etc. (Günther et al., 2001; Mason, 2003; Anonymous, 2006a; Schianetz and Kavanagh, 2008; Hall and Lew, 2009).

The aim of the research was to evaluate tourism as a driving force, its pressures and possible impact. The possible longterm impact of second home tourism and holidaymakers on the Lake Engure drainage area was analysed in depth in this paper.

\section{MATERIAL AND METHODS}

Several methods were applied to determine the pressures and impact on biodiversity by tourism as a driving force. The research was carried out in several stages within the Lake Engure watershed area from January 2010 to August 2011.
The $1^{\text {st }}$ stage involved the study of secondary information sources. Tourism maps and guide books were studied (Veal, 2011) to identify tourism and leisure enterprises, their location and services offered. Period: January - March 2010.

$2^{\text {nd }}$ stage - reconnaissance field studies (Hall, 2011) in the Lake Engures drainage basin, in which visual observations were carried out, significant tourist attractions, transport flows, and parking places were monitored and local tourism entrepreneurs were interviewed to identify the areas in which to carry out surveys during further research. Period April 2010.

$3^{\text {rd }}$ stage - survey. Three types of questionnaires were developed for research purposes - for tourists, owners of second homes, and local inhabitants. The survey of tourists and holidaymakers was carried out during the summer season (May - August) in 2010; the survey of local inhabitants was started in May 2010 and continued throughout the research period. Survey of tourists and holidaymakers was the only way to ascertain their destination, motives, behaviour features and thus also the pressures and impact created by tourists. Holidaymakers were classified as special guests of the territory (visitor category) who did not consider themselves to be strangers (tourists), as they own property and regularly visit the territory.

A random sample (Kristapsone, 2011) was chosen for the survey of second home tourists (holidaymakers) as no data are available in Latvia on second home owners, second home tourism and holidaymakers who live with their friends and relatives.

$53.5 \%$ out of 43 holidaymakers surveyed were men and $46.5 \%$ women; $25.6 \%$ of those surveyed were in the age group 18-24 years, $39.5 \%$ from 25 to 39 years, and $25.6 \%$ from 40 to 54 years. The majority of holidaymakers lived in Rīga (43\% of respondents) and neighbouring towns Tukums (12\%), Talsi (9\%) and Jelgava (9\%).

$4^{\text {th }}$ stage - an audit of tourism enterprises and tourism service providers was carried out in May - September 2011 to precisely ascertain the season of activity, number of people employed and tourists served.

\section{RESULTS}

Tourism as a driving force, tourism services offered. The rapid tourism development in the Lake Engure drainage basin started only after the regaining of independence, as during the Soviet period (till 1991) a part of the territory Mērsrags region was closed for visitors as a USSR border zone (LR State border zone). Therefore, only a part of the coastal area was open for tourists and holidaymakers. Tourism was mainly in the form of use of the lake area for bird hunting and fishing for a restricted group of people, and the Engure Hunting Society was one of the main hunting societies with four boating bases and hunting houses in the USSR Baltic military zone (Grigalis, 2010). 
After Latvia regained independence, the whole Kurzeme coast was open to tourists and the area became an appealing tourist attraction, in particular the Kolka Horn visited by tourists using the P131 Kesterciems - Kolka motorway. Along with transit tourism, the Lake Engure Nature Park (established in 1998) became a significant tourist attraction, although it had existed as a ornithological reserve since 1957. With the renewal of free land sale and reclaiming of former property, inhabitants had the opportunity to use the sea and the lake coast of the territory for their own leisure and recreation as well as offer commercial services to visitors.

Tourism as a driving force was expressed through the tourism infrastructure, commercial activity and services offered. Thirty tourism and hospitality enterprises and 17 tourism service providers operate in the territory, providing 63 permanent and 27 seasonal employment places (Table 1, Fig. 1).

Tourism pressure. Field research and tourist survey results on tourism pressure show that it is not even within the project area. The authors divided the territory into three distinct tourism pressure (impact) zones using factors such as location of tourism resources (appeal and attractions), location of tourism and hospitality enterprises, existing infrastructure, visitor flows and behaviour, amount of holidaymakers and behaviour (Fig. 1).

Zone A (Sea coast zone, Fig. 1) has the greatest tourism pressure, and includes a fragile coastal sand dune area from Engure to Upesgrivva as well as the Lake Engure Nature Park territory on both sides of the motorway P131. The most concentrated tourism pressure can be observed in this zone in the residential areas of Bērzciems and Mērsrags.

Table 1

TOURISM ENTERPRISES, TOURIST ATTRACTIONS AND SERVICES OFFERED IN THE LAKE ENGURES DRAINAGE BASIN AREA IN 2011 (Enterprises' and tourism information centres' data)

\begin{tabular}{l|c|c|c|c}
\hline $\begin{array}{c}\text { Enterprises/ } \\
\text { attractions }\end{array}$ & Number & $\begin{array}{c}\text { No. of beds, } \\
\text { season/off } \\
\text { season }\end{array}$ & $\begin{array}{c}\text { No. of } \\
\text { employed, } \\
\text { season/off } \\
\text { season }\end{array}$ & $\begin{array}{c}\text { No. of } \\
\text { people } \\
\text { served } \\
2010\end{array}$ \\
\hline $\begin{array}{l}\text { Tourism information } \\
\text { providers }\end{array}$ & 2 & - & $0.5 / 0.5$ & 764 \\
Tourist accommodation & 18 & $470 / 148$ & $25 / 5.5$ & 17452 \\
$\quad$ Hotels & 1 & $20 / 20$ & $0.5 / 0.5$ & 200 \\
Camping sites & 4 & $234 / 0$ & $14 / 0$ & 11450 \\
Country houses & 3 & $14 / 2$ & $0.5 / 0$ & 369 \\
Guest houses & 4 & $126 / 116$ & $5 / 4$ & 4140 \\
Holiday homes & 4 & $46 / 0$ & $2.8 / 0$ & 511 \\
Youth hostel & 1 & $1 / 1$ & $1 / 1$ & 282 \\
Boating bases & 1 & $1 / 0$ & $1 / 0$ & 500 \\
Catering enterprises & 8 & $*$ & $28 / 16$ & $*$ \\
Museums & 2 & - & $2.5 / 1.5$ & 5500 \\
Other tourism services & 17 & - & $6.5 / 3$ & 4075 \\
Total & 47 & & $62.5 / 26.5$ & 22841 \\
& & & &
\end{tabular}

\footnotetext{
* no information gathered
}

This zone has a relatively longer tourism and recreation season (from April to October).

Zone B (Lake coast area) includes the territory adjacent to Lake Engure, approximately $0.5 \mathrm{~km}$ inland from the motorway P131. The tourism season in this zone is mainly associated with bird migration in spring and autumn, but the nature trails are mainly used from May to September.

Zone C (Inland zone) includes the rest of the Lake Engure basin, which is relatively less developed in the leisure tourism perspective with low tourist flow, except for a couple of tourist attractions and tourism enterprises (Ridel,u mill, Pastarina museum, Vandzenes manor). Recreationists make short trips to the area at the end of summer and in autumn to gather berries and mushrooms.

Impact of second-home tourism. Owners of second homes and holidaymakers who stayed for a longer period in rented houses or with friends and relatives were surveyed to study the impact. The main results from the holidaymakers' survey indicate that this activity also created pressure on biodiversity and changed the environment and landscape. 3/4 of the holidaymakers surveyed rested in their own second homes (44.2\% of all respondents), summer houses (11.6\%) or with friends and relatives $(18.6 \%)$, and $20.9 \%$ rent rooms or apartments. The majority of holidaymakers $(60.5 \%)$ used the territory longer than five years, of which $18.6 \%$ even longer than 20 years. $25.6 \%$ of respondents have registered the second homes or summer houses as their permanent place of residence.

Answering the question on how often and what is the period of time they spend in the territory, $1 / 5$ th $(20.9 \%)$ answered that they visit every weekend, $32.6 \%$ - every weekend and during their vacations, $9.3 \%$ - only during their vacations, $32.6 \%$ - several times during the year and only $4.5 \%$ once a year.

Similar to tourists (Rozite and Vinklere, 2011), holidaymakers are also attracted by the sea (Table 2), rarely inhabited territory, peace and calmness. The lake as a main value of the territory (appeal factor) was mentioned only in seven cases.

\section{T a ble 2}

MAIN VALUES (FACTORS) THAT APPEAL TO HOLIDAYMAKERS IN THE LAKE ENGURES DRAINAGE BASIN AREA

\begin{tabular}{lcc}
\hline \multicolumn{1}{c|}{ Value (factor) } & $\mathrm{n}=103^{*}$ & $\%$ \\
\hline Sea & 36 & 35.0 \\
Peace and calm & 19 & 18.4 \\
Landscape & 17 & 16.5 \\
Sparsely inhabited & 11 & 10.7 \\
Lake & 7 & 6.8 \\
Distance from place of residence & 5 & 4.9 \\
Reclaimed property & 2 & 1.9 \\
Possibility of reclaiming property & 1 & 1.0 \\
Other factors & 5 & 4.9
\end{tabular}

* multiple answers provided by one and same respondent 


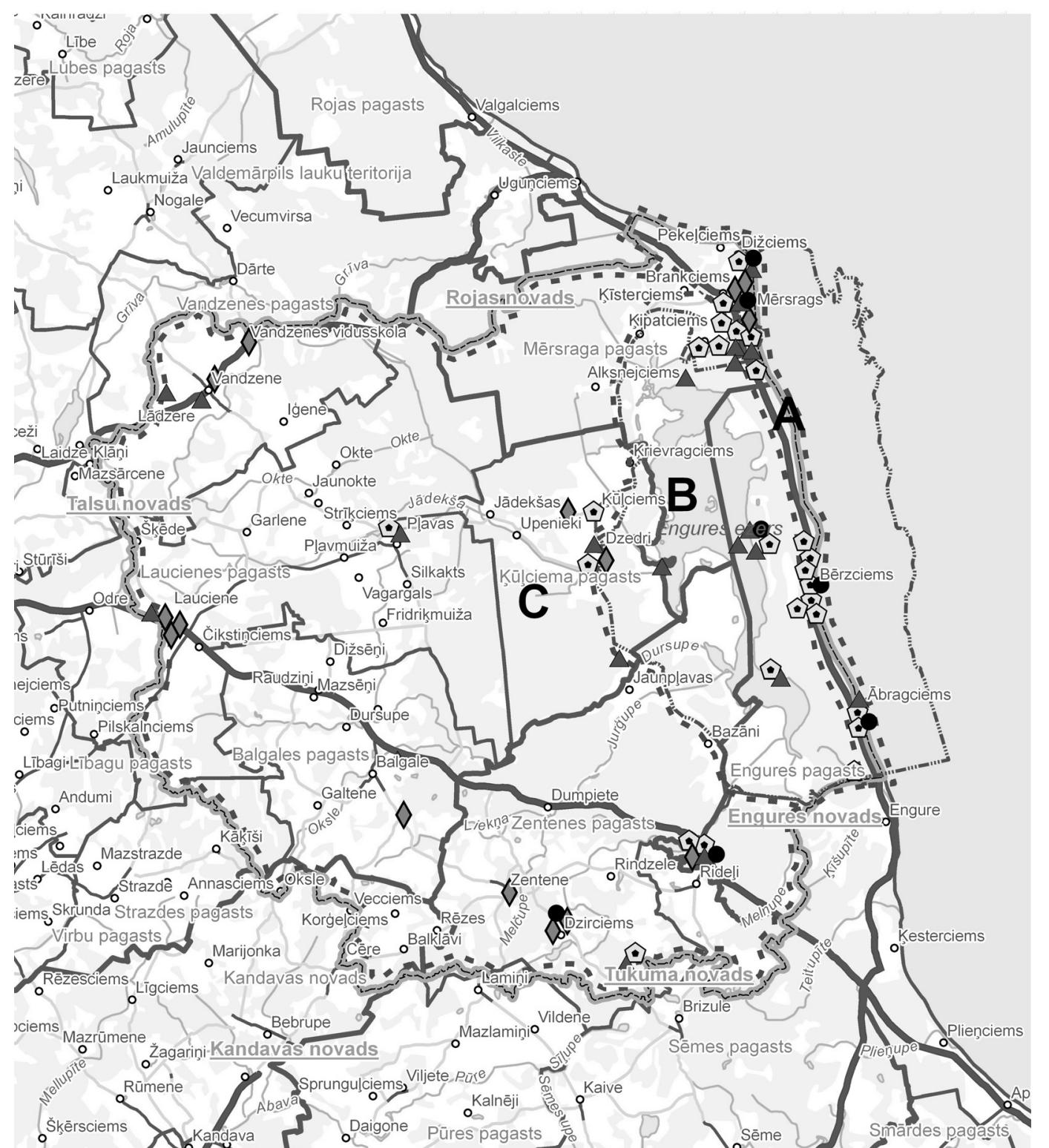

- Second-home resident survey points

\author{
- Tourism services \\ $\checkmark$ Cultural/historical attractions \\ $\triangle$ Natural attractions \\ - - - Tourism impact zones \\ -....... The border of Lake Engure nature park \\ ----- The border of Lake Engure drainage basin area
}

These holidaymakers created air pollution, as $81.4 \%$ arrived here by private transport and only in $30 \%$ of the cases did more than two people arrive together in one car (see also Table 3).

More than a half of respondents $(51.2 \%)$ were not involved in the local social life and activities of the territory. 55.8\% respondents reported that they spent a comparatively large period of time of their vacation/holiday on economic/household activities, mainly gardening. Local trading services were the main services used $(95.3 \%$ of respondents), followed by utility services (30.2\%) and communication services $(23.3 \%)$. $44.2 \%$ of holidaymakers participated in local

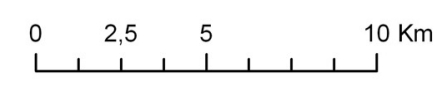

Fig. 1. Tourism attractions and services in Lake Engure watershed area.

cultural events and activities. Only $11.6 \%$ were users of local catering services.

When requested to evaluate the impact of their activities (recreation, behaviour) on the local economy, 60.5\% of respondents answered that they consume products and essential services offered by the shops, $14 \%$ buy local products, $2 \%$ employ local workforce and $37.2 \%$ could not evaluate their impact.

To forecast future behaviour trends, the respondents were asked about their intentions regarding recreation/stay in the territory in the future. $53.5 \%$ of respondents planned to use 
HOLIDAYMAKERS' EVALUATION OF THE IMPACT OF THEIR ACTIVITIES/BEHAVIOUR ON THE SURROUNDING ENVIRONMENT

\begin{tabular}{lcc}
\hline \multicolumn{1}{c|}{ Nature of impact } & $\mathrm{n}=61^{*}$ & $\%$ \\
\hline Maintain the environment & 20 & 32.8 \\
Use water & 17 & 27.9 \\
Leave waste & 6 & 9.8 \\
Maintain, support the infrastructure & 3 & 4.9 \\
Pollute water & 2 & 1.9 \\
Other type of impact & 1 & 1.6 \\
Cannot answer & 12 & 19.7
\end{tabular}

* multiple answers provided by one and the same respondent

the territory in the same way as before, $27.9 \%$ planned to stay more often and, and $11.6 \%$ would indicated intention to relocate there after their retirement.

\section{DISSCUSSION}

The locations of tourism resources, attractions and services indicated that it was not possible to unequivocally forecast the possible tourism impact on the biodiversity in the territory under research and different forecasts were necessary for three distinct zones. Most attention should be paid to the sea coastal zone (Zone A), as it had the largest flow of tourists and concentration of holidaymakers and recreationists, while being a very sensitive, easily vulnerable natural environment — sand dune zone. Taking into consideration global trends, the southern part of Baltic Sea coastal zone in future be the area might be expected to have the greatest demand for tourism and recreation, and therefore, the greatest pressure could be expected in this zone. Lately, this pressure has remained unchanged, due to the economic recession in Latvia and worldwide and consequently the decrease in the demand for tourism and recreation services, and associated crisis in the real estate market. The demand for land properties and the number of inhabitants who would build their summer houses (second homes) near the sea coast area will definitely increase with the stabilisation of the economy. While the environmental impacts of second home tourism are minor, compared with other tourism activities, their impacts cannot be ignored, especially mobility caused by second home tourism. It was estimated in Finland that $79 \%$ of all energy consumption related to Finnish second-home tourism was the result of travelling (Hiltunen, 2007, p. 256).

The local municipality could help control the pressure and balance the impact, by supervising tourism and recreation development using local and European Union financial resources and preventing unauthorised, uncontrolled tourism development, improving the transport infrastructure and parking facilities, and educating inhabitants and visitors. The Engure and Mērsrags municipalities can, when required, use instruments under their competence to restrict tourist flows and tourism related activities.
The second tourism zone, the lake coast (zone B), is a vulnerable territory, but its use is regulated by the nature park status of the Lake Engure. The main activities in the zone are bird watching and orchid trails, which attract mainly nature oriented tourists, eco-tourists, and bird watchers, who, in comparison to mass tourists, are more tolerant towards the environment and understand the consequences of their activities. Therefore, a forecast of higher interest of tourists towards nature values, green holidays, activities in nature or even a bigger number of tourists in the Lake Engure basin, would not be associated with a considerable increase in pressure on biodiversity. Tourist behaviour could mostly harm birds, their nesting and migration.

The third, Inland zone (Zone C), has relatively low tourism development potential and there is no noticeable second home construction or development. Therefore, forecasting development in this territory, tourism and recreation cannot be considered as a major driving force. Considering its location between the two urban areas, Engure and Talsi, and geographical isolation from the sea coast (behind Engure Lake), it will probably retain its depressive territorial characteristic features, that at present can be observed in rural territories further away from inhabited areas, such as in Lauciena and Vandzene.

Tourism pressure in the whole Lake Engures drainage basin is relatively low. Tourism as an economic activity is relatively poorly developed, as only just below one and half thousand beds are available during the summer season, with about 17 thousand overnights. Considering the local population ( $\sim 6$ thousand, 2010) and comparing the tourism intensity (the ratio of nights spent in tourist accommodation relative to the total permanent resident population of the area, with other European coastal territories (Anonymous, 2011), the level of tourism intensity in the whole Baltic Sea region (2.8) is near the European average of 2.1-3.0 (Anonymous, 2006b).

The coastal territory does not have any attractions of national significance, and therefore, there is no ground to predict high tourist flows. There are not many tourist attractions in the vicinity that cannot be visited within a day, and therefore, the territory will likely be used in the future mostly as a transit territory. Tourists, who come mainly from Rīga, which is just 70-80 km distant, will not be interested in finding overnight accommodation.

A major impact is forecast from second home tourism. The coastal territory already has many summer houses and a part of the previous living houses are used only during the summer season. With the improvement in the economic situation, the Engure region coast will be attractive to more affluent migrants, who may relocate to the attractive sea coast as a permanent place of residence, commuting to their workplaces in Rìga. Although the pressure of holidaymakers and second home owners on the environment will likely increase, it will still be lower than the pressure created by commercial tourist accommodation. Second home owners who plan to use their property more often or even relocate 
to reside here are more responsible towards the environment and will take effort to preserve the value and uniqueness of the natural environment, as they consider themselves belonging to the place or even as local inhabitants.

Taking into account that fishing is losing its significance in coastal municipalities, and that tourism is becoming one of the significant activities, it is possible that concrete solutions may be required for tourism and recreation development, to balance the economic interests of the local inhabitants and preservation of the natural environment.

\section{ACKNOWLEDGEMENTS}

This paper was prepared with the support of the Latvian Council of Science financed project "Development of Conceptual Integrated Model of Socioeconomic Biodiversity Pressures, Drivers and Impact for the Long-Term Socioecological Research Platform of Latvia” (2010-2012).

\section{REFERENCES}

Anonīms (2011). Latvijas republikas Centrālā statistikas pārvalde. Tūrisms Latvijā 2011. Statistisko datu krājums. Rīga: Centrāāā statistikas pārvalde. 63 lpp.

Anonīms. LR Valsts Robežsardze. Vēsture. Available at:

http://www.rs.gov.lv/index.php?id=786\&top= (in Latvian), last accessed 15 August 2011

Anonymous (1999). Environmental Indicators: Typology and Overview. Technical Report No 25. European Environment Agency, Copenhagen. Available at: http://www.eea.europa.eu/publications/TEC25, last accessed 11 August 2011.

Anonymous (2005). The European Environment - State and Outlook 2005. Copenhagen: European Environment Agency. 584 pp.

Anonymous (2006a). Methodological Work on Measuring the Sustainable Development of Tourism. Part.1: Technical Report. European Commission. Office for Official Publications of the European Communities, Luxembourg. Available at: http://epp.eurostat.ec.europa.eu/cache/ ITY_OFFPUB/KS-DE-06-001/EN/KS-DE-06-001-EN.PDF, last accessed 2 August 2011.

Anonymous (2006b). Standard Indicator Format and Indicator Fact Sheet: 14. Intensity of tourism. DEDUCE. Available at: http://www.deduce.eu/ results.html, last accessed 22 October 2011.

Anonymous (2007). Europe's Environment. The Fourth Assessment. Copenhagen: European Environment Agency. 452 pp.

Anonymous (2010a). Assessing Biodiversity in Europe - the 2010 Report. No. 5/2010. Copenhagen: European Environment Agency. 64 pp.
Anonymous (2010b). The European Environment: State and Outlook 2010: Biodiversity. Copenhagen: European Environment Agency. 48 pp.

Anonymous (2011). Glossary: Tourism intensity. Eurostat. Available at: http://epp.eurostat.ec.europa.eu/statistics_explained/index.php/Glossary: Tourism_intensity, last accessed 20 October 2011.

Cohen, E. (2008). The changing faces of contemporary tourism. Soc., 45(4), 330-333.

Flogenfeldt, T. Jr. (2006). Second homes, work commuting and amenity migrants in Norway's mountain areas. In: Moss, L.A.G. (Ed.). The Amenity Migrants - Seeking and Sustaining Mountains and Their Cultures (pp. 232-244). Cambridge: CABI.

Grigalis, J. (2010). Baltijas kara apgabala virspavēlnieka medību namiņš Engures medību saimniecībā. Available at:

http://www.celotajs.lv/e/story/view/mersragarobezapsardze/ff808081276 fd8180127710dfb3a0021 16 August 2011 (in Latvian).

Günther, W., Danielson, J., Koch, A., Lohman, M.S., Sonntag, U., Volmert, K., Ziesemer, K. (2001). Indicators for the Development of Sustainable Tourism in the Baltic Sea Region. Forschungsbericht 31201 129/ UBA-FB 000242e, Texte 68/01 des Umweltbundesamtes. Berlin (UBA).

Hall, C.M. (2011). Fieldwork in tourism/touring fields. In: Hall, C.M. (Ed.) Fieldwork in Tourism. Methods, Issues and Reflections (pp. 7-18). Routledge/Taylor \& Francis Group, London and New York.

Hall, C.M., Lew, A.A. (2009). Understanding and Managing Tourism Impacts: An Integrated Approach. London and New York: Routledge. $365 \mathrm{pp}$.

Hall, C.M., Müler, D.K. (eds.) (2004). Tourism, Mobility and Second Homes: Between Elite Landscape and Common Ground. Clevedon: Channel View Publications. 304 pp.

Hall, C.M., Page, S.J. (2006). The Geography of Tourism and Recreation. Environment, Place and Space. $3^{\text {rd }}$ ed. London and New York: Routledge, 427 pp. at pp. $1-33 ; 144-171$.

Hiltunen, M.J. (2007). Environmental impacts of rural second home tourism - case Lake District in Finland. Scan. Jour. Hosp. Tour., 7(3), 243-265.

Kristapsone, S. (2011). Izlase un tās veidošanas metodes. Ievads pētniecībā: stratēgijas, dizaini, metodes. Rīga: Raka, 69.-81. lpp. (in Latvian).

Mason, P. (2003). Tourism Impacts, Planning and Management. Oxford, UK: Elsevier Butterworth-Heinemann. 208 pp.

Müller, D.K. (2002). Reinventing the countryside: German second-home owners in Southern Sweden. Curr. Iss. Tour., 5(5), 426-447.

Rozite, M., Vinklere, D. (2011). Evaluation of tourism and recreation pressure and impact on Engure lake's drainage basin area. Human resources the main factor of regional development. J. Soc., 4, 141-147.

Schianetz, K. \& Kavanagh, L. (2008). Sustainability indicators for tourism destinations: A complex adaptive systems approach using systemic indicator systems. J. Sust. Tour., 16(6), 601-628.

Veal, A.J. (2011). Research Methods for Leisure and Tourism: A Practical Guide. $4^{\text {th }}$ ed. Financial Times/ Prentice Hall. 559 pp.

Williams, S. (2009). Tourism Geography: A New Synthesis. $2^{\text {nd }}$ ed. London and New York: Routledge. 309 pp.

Received 27 December 2011

\section{TŪRISMS UN REKREĀCIJA KĀ DZINĒJSPĒKS BIOLOG̣ISKĀS DAUZDVEIDĪBAS IZMAIN̦U PROGNOZĒM - ENGURES EZERA SATECES BASEINA PIEMĒRS}

Pētījuma mērkis ir novērtēt tūrismu kā dzinējspēku un tā spiedienu atbilstoši Eiropas Vides aǵentūras (EEA) izmantotajam DPSIR (dzinējspēki, spiediens, galarezultāts, ietekme, atbildes reakcija) ietvaram Engures ezera sateces baseinā, lai varētu prognozēt iespējamās ilgtermina izmainas biodaudzveidībā. Izmantojot sekundāro datu avotus, lauku pētījuma datus un atpūtnieku anketēšanas datus, ir izveidota teritorijas karte, kurā izdalītas trīs atškirīgas tūrisma zonas. Novērtēti tūrisma uzṇēmumi un pakalpojumu sniedzēji kā dzinējspēks un to radītais spiediens, apkopoti statistiskie dati par teritorijas tūrisma mītṇu kapacitāti sezonā un nesezonā, tūrisma nozarē nodarbināto skaitu, apkalpoto tūristu skaitu. Lai novērtētu vasarnīcu tūrisma iespējamo ietekmi, anketēti vasarnīcu īpašnieki un atpūtnieki, novērtēta to izturēšanās, izmantotie vietējie pakalpojumi, iesaistǐšanās pašvaldībā notiekošajos procesos un nākotnes nodomi. Rezultātā secināts, ka tūrisms un rekreācija kā dzinējspēks visaktīvāk darbosies piekrastes zonā, bet neradot lielas tūristu plūsmas. Pētījumu teritorija galvenokārt tiks izmantota tranzītā, vienas dienas apskatei, atpūtas tūrismam un rekreācijai. 